\title{
POLA KUMAN PADA PASIEN BARU \\ INFEKSI MENULAR SEKSUAL \\ DI POLIKLINIK KULIT DAN KELAMIN \\ RSUP. PROF. Dr. R.D. KANDOU MANADO \\ PERIODE NOVEMBER 2010 S.D NOVEMBER 2012
}

\author{
${ }^{1}$ Fitri Yanti Tanaiyo \\ 'John Porotu'o \\ ${ }^{2}$ Standy Soeliongan \\ ${ }^{1}$ Kandidat Skripsi Fakultas Kedokteran Universitas Sam Ramtulangi \\ ${ }^{2}$ Bagian Mikrobiologi Universitas Sam Ratulangi \\ Email: fitritanaiyo09283@yahoo.com
}

\begin{abstract}
STIs (Sexually Transmitted Infections) are diseases which is transmitted through sexual contact (oral, vaginal, anal) with an infected person. WHO (World Health Organization) in 2001 estimated STI patients around the world as much as 340 million people. This research uses descriptive retrospective study in November 2012 to January 2013 where conducted in the department of dermatology clinic at Prof.Dr.R.D.Kandou General Hospital, Manado. The research sample is a new STI patients who come for treatment at the clinic that had microbiological laboratory examination such as direct examination and gram staining examination. Based on data collected from 163 patients who had a new IMS and had direct microbiological examination for trichomonas only one patient was found positive result that 38 years old female. Based on gram stain examination, 83 patients were found positive results. Based on gram stain examination for pseudohyphae, 24 (14,7\%) patients with positive results. 18 of them females and 11 where in the age group 20-29 years. Among 163 patients there were 10 (6,1\%) patients were positive results of gram positive bacilli, seven among them are females and in all age groups. For gram negative bacilli obtained positive results in $24(14,7 \%)$ of 163 patients, 15 of them are females and most in the age group 20-29 years. Among 163 patients, 9 patients (5,5\%) were found positive results for gram positive diplococcus, 8 males and the highest number in the age group 20-29 years for gram negative diplococcus obtained positive results in $16(9,8 \%)$ of 163 patients, 15 of them in males and highest number in the age group 20-29 years. The presence of STIs are in increasing every year due to lack of attention from the healthy centers and the lack of knowledge about the causes and consequences of STIs. The socialization of STIs and adolescence's sex education are important for STIs preventions.
\end{abstract}

Keywords: Sexually Transmitted Infection, Sexually Transmitted Disease

Abstrak: IMS (Infeksi Menular Seksual) adalah penyakit yang menular melalui hubungan seksual (oral, vaginal, anal) dengan orang yang telah terinfeksi. WHO (World Health Organization) pada tahun 2001 memperkirakan penderita IMS diseluruh dunia sebanyak 340 juta orang. Jenis penelitian ini 
menggunakan metode deskriptif retrospektif dengan waktu penelitian pada bulan November 2012 sampai Januari 2013 yang dilaksanakan di Poliklinik Kulit dan Kelamin RSUP Prof.Dr.R.D.Kandou, Manado. Sampel penelitian adalah pasien IMS baru yang datang berobat yang telah menjalani pemeriksaan laboratorium mikrobiologi langsung dan pewarnaan gram. Berdasarkan data yang diambil dari 163 pasien yang telah dilakukan pemeriksaan mikrobiologi langsung untuk trikomonas didapati satu pasien yang hasilnya positifyaitu pasien perempuan usia 38 tahun. Dari pewarnaan gram didapatkan 83 pasien dengan hasil positif. Untuk pseudohifa, hasil positif pada 24 orang (14,7\%), 18 diantaranya pada perempuan dan 11 diantaranya pada kelompok usia 20-29 tahun. Dari pewarnaan gram didapati dari 163 pasien ada 10 orang (6,1\%) yang hasil positif basil gram positif, 7 diantaranya pada perempuan dan terdapat pada semua kelompok usia. Untuk basil gram negatifdidapatkan hasil positif pada 24 (14,7\%) dari 163 pasien, 15 diantaranya pada perempuan dan terbanyak pada kelompok usia 20-29 tahun. Dari 163 pasien didapatkan hasil positif untuk diplokokus gram positif sebanyak 9 orang (5,5\%), 8 diantaranya pada pria danjumlah terbanyak pada kelompok usia 20-29 tahun. Untuk diplokokus gram negatif didapatkan hasil positif pada $16(9,8 \%)$ dari 163 orang pasien, 15 diantaranya pada pria dan terbanyak pada kelompok usia 20-29 tahun. Terjadinya kasus IMS yang meningkat setiap tahunnya diduga karena kurangnya perhatian dari pusat kesehatan dan kurangnya pengetahuna tentang sebab dan akibat dari IMS. Banyaknya sosialisasi tentang IMS dan pendidikan seks pada usia dini pent ing untuk pencegahan IMS.

Kata kunci: Infeksi Menular Seksual, Penyakit Menular Seksual

Nama lain dari IMS (Infeksi Menular Seksual) adalah PMS (Penyakit Menular Seksual), STD (Sexual Transmitted Diseases), STI (Sexual Transmitted Infection), dan veneral disease (venus = dewi cinta). ${ }^{1,22}$ Pada prakteknya, banyak IMS yang tidak menunjukan gejala (asimptomatik), sehingga mempersulit pemberantasan dan pengendalian penyakit ini. ${ }^{1}$

WHO (World Health Organization) pada tahun 2001 memperkirakan penderita IMS diseluruh dunia sebanyak 340 juta orang. Sebagian besar penderita berada di Asia Selatan dan Asia Tenggara yaitu sebanyak 151 juta, diikuti Afrika sekitar 70 juta, dan yang terendah adalah Australia dan Selandia Bam sebanyak satu juta. Semakin lama jumlah penderita IMS semakin meningkat dan penyebarannya semakin merata diseluruh dunia. WHO memperkirakan morbiditas IMS di dunia sebesar kurang lebih 250 juta orang setiap tahunnya. ${ }^{1}$

Pusat pengawasan penyakit di Amerika Serikat memperkirakan bahwa setiap tahunnya paling sedikit ada sekitar 8-10 juta orang Amerika terserang penyakit kelamin. Penyakit kelamin sering menjangkit kelompok usia dengan kegiatan orang yang aktif, yaitu usia 15-30 tahun. ${ }^{2}$ Di Amerika IMS terjadi pada semua orang dengan berbagai latar belakang, tapi paling banyak pada kelompok umur 15-24 tahun, dan paling banyak terjadi pada wanita ras Afrika-Amerika. ${ }^{22}$

Di Indonesia, angka prevalensi IMS bervariasi menurut daerah.Hasil survey ISR (Infeksi Saluran Reproduksi) tahun 2005 melaporkan angka IMS di kalangan WTS di Bitung 35\%, Jakarta 40\%, dan Bandung 50\%. Hasil laporan periodic presumptive treatment (PPT) periode I bulan Januari 2007 menunjukkan hasil yang hamper sama, yaitu angka IMS di Banyuwangi 74,5\%; Denpasar 36,6\%; Surabaya 61,21\%; dan Semarang 79,7\%. 
Monitoring secara akurat insidensi dan prevalensi pada pasien IMS dari berbagai populasi sangatlah penting, terutama pada kelompok usia dewasa muda agar dapat diketahui tingkat efektifitas dari upaya pencegahan yang telah dilakukan. $^{25}$

IMS dapat disebabkan oleh bakteri, virus, jamur, protozoa, atau ektoparasit. Gejala klinik dari masing-masing penyebab hampir sama sehingga pemeriksaan laboratorium mikrobiologi sangat dibutuhkan untuk menentukan organisme penyebab infeksi. ${ }^{8}$

Pemeriksaan $\mathrm{KOH}$ merupakan pemeriksaan mikroskopik langsung untuk mengidentifikasi struktur jamur dan merupakan teknik yang cepat, sederhana, terjangkau dan telah digunakan secara luas sebagai teknik skrining awal. Teknik ini hanya memiliki sensitivitas hingga $80 \%$ dan spesifisitas hingga $70 \%{ }^{4}$

Pewarnaan Gram merupakan salah satu teknik pewarnaan, dapat membedakkan dua tipe dinding sel yang menyusun bakteri. Dari system pewarnaan ini dapat diklasifikasikan dua jenis bakteri, yaitu bakteri Gram Positif dan bakteri Gram Negatif. ${ }^{15}$ Sebagian besar specimen yang diserahkan ketika dicurigai terjadi infeksi oleh bakteri, hams dihapus pada slide kaca, diberi pewarnaan Gram, dan diperiksa dibawah mikroskop. Pada pemeriksaan mikroskop, reaksi Gram (ungu-biru menunjukkan organisme gram positif; merah, gram negative) dan morfologi (bentik: kokus, batang, fusiformis, atau Iain-lain) pada bakteri hams diperhatikan. Beberapa bakteri gram positif yang tidak hidup dapat berwarna seperti gram negatif. ${ }^{4}$

\section{METODE PENELITIAN}

Penelitian ini menggunakan metode deskriptif retrospektif, yaitu suatu metode yang digunakan dalam penelitian yang berdasarkan pengumpulan data yang nantinya akan diolah menurut bebrapa variable agar tercapainya suatu validitas data. Penelitian ini dilaksanakan pada November 2012 - Januari 2013 dan pengambilan data pasien dilakukan di Poliklinik Kulit dan Kelamin RSUP Prof.Dr.R.D.Kandou, Manado.Populasi penelitian adalah semua pasien baru yang dating berobat di Poliklinik Kulit dan Kelamin RSUP Prof.Dr.R.D.Kandou, Manado dan khususnya yang diperiksa di klinik IMS dan yang dilakukan pemeriksaan laboratorium mikrobiologi langsung dan pewarnaan gram. Kriteria inklusi dari penelitian ini yaitu pasien IMS yang bersedia menjadi sampel penelitian, sedangkan kriteria eksklusinya yaitu pasien IMS dengan penyakit penyerta lain atau dengan komplikasi lain misalnya pasien IMS dengan komplikasi kista ovarium dan pasien yang tidak bersedia menjadi sampel penelitian.Variable penelitian terdiri dari umur yaitu usia pasien yang tercatat dalam rekam medic yang dibagi dalam bebrapa kelompok umur, jenis kealim yang dinyatakan dalam pria dan wanita, pekerjaan yang dibagi dalam beberapa kelompok, dan hasil pemeriksaan laboratorium mikrobiologi yaitu jenis-jenis mikroorganisme yang ditemukan pada pemeriksaan langsung serta pewarnaan gram.

Alat dan bahan yang digunakan dalam penelitian ini berupa catatan rekam medic pasien IMS di Poliklinik Kulit dan Kelamin RSUP Prof.Dr.R.D.Kandou, Manado periode November 2010 sampai dengan November 2012, alat tulis menulis, perangkat computer dan berbagai literature. Data dari catatan rekam 
medic kemudian dikelompokkan berdasarkan variable penelitian lalu disajikan dalam bentuk teks dan tabel.

\section{HASIL PENELITIAN}

Berdasarkan penelitian yang dilakukan di Poliklinik Kulit dan Kelamin RSUP Prof. dr. R.D Kandou Manado periode November 2010 -- November 2012 maka ditemukan 163 pasien baru dengan diagnosis IMS dimana semua pasien tersebut telah melakukan pemeriksaan laboratorium mikrobiologi.

Pemeriksaan laboratorium mikrobiologi yang dibahas disini adalah pemeriksaan langsung dan pewarnaan gram.Dari pemeriksaan langsung untuk melihat apakah adanya trikomonas didapati hanya satu pasien yang hasilnya positif sedangkan 162 diantaranya hasilnya negatif.

Tabel 5. Frekuensi dan persentase hasil pemeriksaan langsung untuk trikomonas

\begin{tabular}{lll}
\hline & \multicolumn{1}{c}{ Frekuensi } & Persentase \\
\hline Hasil positif & 1 & $6 \%$ \\
Hasil negatif & 162 & $99,4 \%$ \\
\hline Total & 163 & $100 \%$ \\
\hline
\end{tabular}

Dari pewarnaan gram didapatkan pseudohifa dengan hasil positif pada 24 orang (14,7 \%) dan 139 orang pasien dengan hasil negatif (85,3\%).

Tabel 6. Frekuensi dan pemeriksaan gram untuk pseudohifa

\begin{tabular}{lll} 
& \multicolumn{3}{c}{ Frekuensi } & Persentase \\
\hline Hasil positif & 24 & $14,7 \%$ \\
Hasil negatif & 139 & $85,3 \%$ \\
\hline Total & 163 & $100 \%$ \\
\hline
\end{tabular}

Pada pewarnaan gram juga didapatkan 153 pasien atau 93,9\% pasien dengan hasil negatif basil gram positif dan 10 orang atau 6,1\% pasien dengan hasil positif basil gram positif. Sedangkan untuk basil gram negatif terdapat 139 orang atau 85,3\% pasien dengan hasil negatif dan 14,7 \% atau 24 orang dengan hasil positif.

Tabel 7. Frekuensi dan percentage hasil pemeriksaan gram untuk basil gram positif

\begin{tabular}{llll}
\hline & & Frekuensi & Persentase \\
\hline Hasil positif & 10 & $6,1 \%$ \\
Hasil negatif & 153 & $93,9 \%$ \\
\hline Total & 163 & $100 \%$ & \\
\hline
\end{tabular}

Tabel 8. Frekuensi dan persentase hasil pemeriksaan gram untuk basil gram negatif 


\begin{tabular}{llll}
\hline & & Frekuensi & Persentase \\
\hline Hasil positif & 24 & & $14,7 \%$ \\
Hasil negatif & 139 & $85,3 \%$ \\
\hline Total & 163 & $100 \%$ \\
\hline
\end{tabular}

Selanjutnya untuk diplokokus gram positif dari 163 orang terdapat 9 orang atau 5,5\% dengan hasil positif dan 154 orang atau 94,5\% dengan hasil negatif. Untuk diplokokus gram negatif terdapat 16 orang dengan hasil positif atau 9,8\% dan 147 orang dengan hasil negatif atau 90,2\%.

Tabel 9. Frekuensi dan persentase hasil pemeriksaan gram untuk diplokokus gram positif

\begin{tabular}{llll}
\hline & & Frekuensi & Persentase \\
\hline Hasil positif & 9 & $5,5 \%$ \\
Hasil negatif & 154 & $94,5 \%$ \\
\hline Total & 163 & $100 \%$ & \\
\hline
\end{tabular}

Tabel 10. Frekuensi dan persentase hasil pemeriksaan gram untuk diplokokus gram negatif

\begin{tabular}{|c|c|c|}
\hline & Frekuensi & Persentase \\
\hline Hasil positif & 16 & $9,8 \%$ \\
\hline Hasil negatif & 147 & $90,2 \%$ \\
\hline Total & 163 & $100 \%$ \\
\hline
\end{tabular}

Berdasarkan distribusi umur pasien yang diteliti didapati bahwa IMS paling banyak terjadi pada kelompok umur 20 - 29 tahun yaitu sebanyak 52 kasus (31,9\%) dan paling sedikit pada kelompok umur 75 tahun keatas yaitu sebanyak 2 kasus (1,2\%). Data-data ini menunjukkan bahwa IMS paling sering terjadi pada dewasa muda. 
Grafik. 1 Distribusi kasus IMS berdasarkan umur

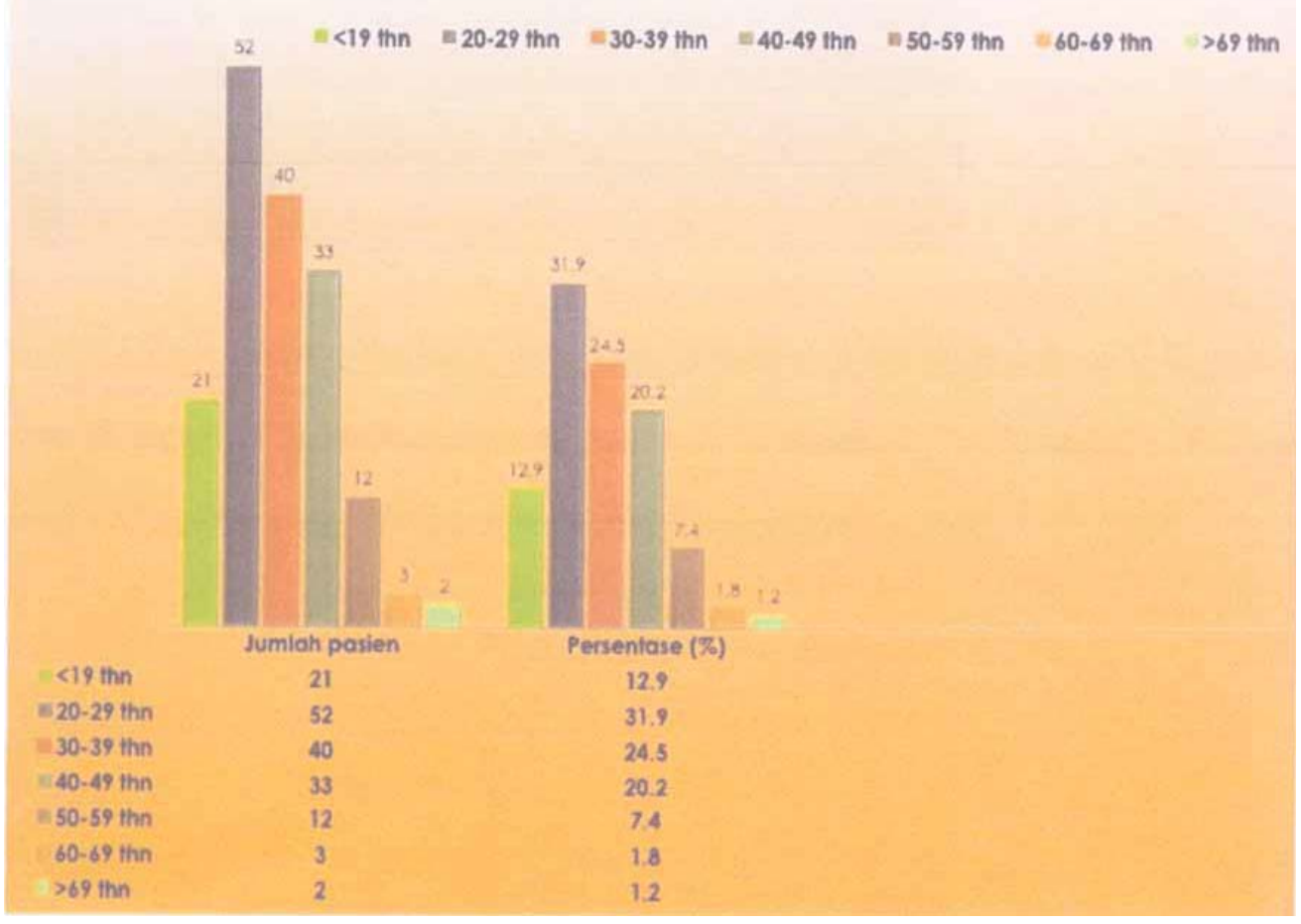

Berdasarkan distribusi jenis kelamin didapati bahwa IMS paling banyak terjadi pada pasien dengan jenis kelamin perempuan yaitu sebanyak 84 pasien (51,5\%) dan pada pasien dengan jenis kelamin laki-laki 79 pasien (48,5\%).

Grafik.2 Distribusi kasus IMS berdasarkan jenis kelamin

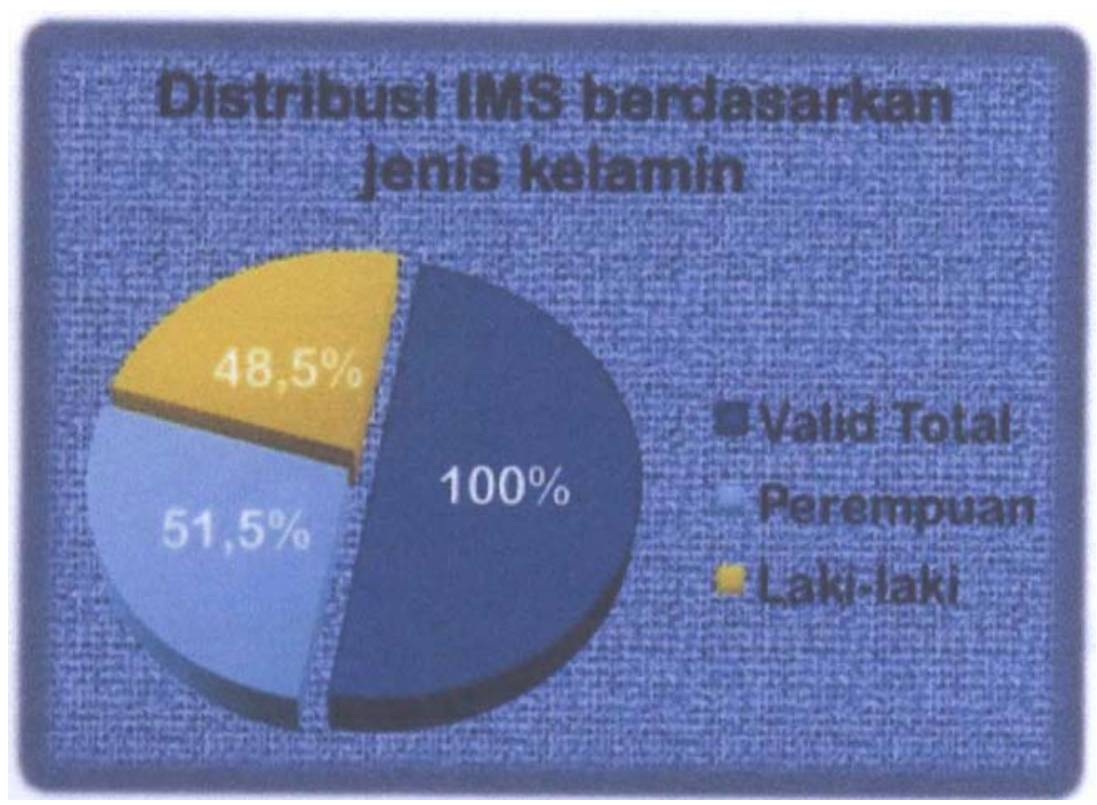


Untuk faktor pekerjaan, dari hasil penelitian didapatkan bahwa IMS paling banyak terjadi pada profesi pegawai swasta yaitu sebesar 27\% diikuti IRT 16\% dan PNS 15,3\%.Dan yang paling rendah pada pelaut sebanyak $1,2 \%$.

Tabel. 11 Distribusi IMS berdasarkan pekerjaan

\begin{tabular}{lll}
\hline & Frekuensi & Persentase \\
\hline PNS & 25 & $15,3 \%$ \\
Wiraswasta & 7 & $4,3 \%$ \\
Swasta & 44 & $27,0 \%$ \\
Guru & 4 & $2.5 \%$ \\
Petani & 4 & $2,5 \%$ \\
Pelaut & 2 & $1,2 \%$ \\
IRT & 26 & $16,0 \%$ \\
Mahasiswa & 16 & $9.8 \%$ \\
Pelajar & 9 & $5,5 \%$ \\
Lainnya (Polti, tukang, & & \\
pensiunan, pengangguran, & 26 & $16,0 \%$ \\
pedagang, supir, perawat) & & \\
Total & 163 & $100 \%$ \\
\hline
\end{tabular}

\section{BAHASAN}

Kriteria sampel yang diteliti adalah pasien yang tercatatat dalam rekam medik yang merupakan pasien ham yang datang memeriksakan diri klinik IMS Poliklinik Kulit dan Kelamin RSUP Prof. dr. R.D Kandou Manado periode November 2010 -November 2012 yang melakukan pemeriksaan laboratorium mikrobiologi. Jumlah sampel yang diteliti yaitu sebanyak 163 pasien dengan diagnosis IMS.

Pada penelitian sebelumnya dengan melakukan pemeriksaan mikrobiologi berupa pemeriksaan langsung dan pewarnaan gram yang dilakukan di 4 puskesmas di Jakarta pada tahun 1994-1995 dengan total sampel 1136 sampel ditemkan 40-45\% atau sekitar 455-512 dari sampel tersebut hasilnya positif IMS (Pratomo, Kodim, et al., 1995: 66-67). ${ }^{12}$

Dari hasil pemeriksaan laboratorium mikrobiologi yang dilakukan yang saya temukan pada data rekam medik pasien didapatkan bahwa diagnosis terbanyak yang didapat dari sampel penelitian yaitu Gonore serta Kandidosis Vulvovaginalis dan Balanopostitis. Hasil yang didapatkan ini bisa sama dan juga bisa berbeda dengan hasil yang didapatkan pada penelitian-penelitian sebelumnya yang telah dilakukan.

Penelitian sebelumnya yang dilakuan di RSUD. Koja dan Puskesmas Cilincing, Jakarta Utara periode Januari-April 1997 dari 312 sampel penelitian yang keseluruhannya berjenis kelamin perempuan ditemukan 77 sampel penelitian $(24,7 \%)$ dengan hasil positif dengan berbagai jenis IMS yang bias dilihat pada label 12 berikut $^{12}$ :

Tabel 12. Hasil penelitian IMS di RSUD. Koja dan Puskesmas Cilincing, Jakarta Utara 1997

$\begin{array}{llll}\text { Jenis IMS } & \text { RSUD.Koja } & \begin{array}{c}\text { Puskesmas } \\ \text { Cilincing }\end{array} & \text { Hasil Digabungkan }\end{array}$




\begin{tabular}{lcccccc} 
& $\mathrm{n}$ & $\%$ & $\mathrm{n}$ & $\%$ & $\mathrm{n}$ & $\%$ \\
\hline Kandidiasis & 11 & 7,6 & 10 & 5,9 & 21 & 6,7 \\
Bakterial Vaginosis & 8 & 5,5 & 8 & 4,8 & 16 & 5,1 \\
Trikomoniasis & 13 & 9,0 & 4 & 2,4 & 17 & 5,4 \\
GO & 1 & 0,7 & 0 & 0,0 & 1 & 0,3 \\
Klamidia & 18 & 12,6 & 13 & 8,3 & 31 & 10,3 \\
Sifilis & 0 & 0,0 & 0 & 0,0 & 0 & 0 \\
Total & & & & & 77 & 24,7 \\
\hline
\end{tabular}

Hasil pada Tabel 12 berbeda dengan hasil yang ditemukan di klinik kesehatan wanita di Bali pada Januari 2001 dengan jumlah sampel yang sama yaitu 312 yang seluruhnya perempuan dengan hasil 201 sampel (64,4\%) positif: Kandidiasis 5,8\%, Bakterial Vaginosis 37,2\%, Trikomoniasis 15,1\%, GO 0,7\%, Klamidia 5,6\% dan Sifilis 0,0\%. ${ }^{13}$ Berdasarkan sebuah penelitian oleh SUN Study, Amerika dengan 557 orang partisipasn, 13\% terdiagnosis IMS yang diantaranya rectal. Klamida, orofaringeal.Gonore, uretritis Klamidia ada pria dan Trikomoniasis pada wanita. 94\% dari insidens tersebut teridentifikasi pada hubungan seksual yang dilakukan sesama pria. ${ }^{19}$ Studi lainnya di Amerika juga menyebutkan bahwa terdapat 18,9 juta kasus IMS pada tahun 2000 dan 9,1 juta (48\%) terjadi pada kelompok usia 15-24 tahun. Tiga jenis IMS terbesar yaitu HPV, Trikomoniasis dan Klamidia yaitu sekitar 88\% kasus dan terjadi pada usia 15-24 tahun. Hal ini dikarenakan kurangnya tindakan pencegahan dan kontrol penyakit. ${ }^{25}$

Antara tahun 1950 sampai 2010 ada 105 penelitian yang dilakukan oleh 25 studi yang melaporkan tentang prevalensi IMS di Papua Nugini. Jenis IMS tertinggi yaitu Klamidia (26,1\%), Gonore (33,6\%), Sifilis (33,1\%) dan Trikomonas (39,3\%).Sedangkan untuk kasus HIV sendiri didapatkan hasil 1,8\% pada pria, 2,6\% pada wanita dan 11,8\% pada PSK. Hal ini dikarenakan perilaku seksual yang bebas dan tidak aman, kurangnya pengetahuan atau rendahnya tingkat pendidikan serta kurangnya kesadaran dari tiap individu tentang sebab akibat dari IMS. ${ }^{17}$ Dari hasil studi yang pernah dilakukan di Amerika disebutkan bahwa meningkatnya isidensi IMS dapat disebabkan oleh protokol skrining yang tidak efektif dan kurangnya perhatian dari pusat kesehatan serta kurangnya kontrol penyakit dan tindakan pencegahan. ${ }^{18,24,25}$

Dari hasil penelitian saya, berdasarkan distribusi pasien IMS menurut pola kuman dari hasil pemeriksaan laboratorium mikrobiologi, yang paling sering menyebabkan IMS adalah kuman gram negatif yaitu basil gram negatif pada 24 orang pasien atau sekitar 14,7\%, pseudohifa 14,7 \% dan diplokokus gram negatif pada 16 orang pasien atau sekitar 9,8 \%. Dan dari penelitian ini didapatkan bahwa perempuan lebih sering mendapatkan IMS dibandingkan laki-laki yaitu sebanyak 84 pasien perempuan (51,5 \%) dan 79 pasien laki-laki (48,5\%). Menurut Satiti R dari Bagian/SMF Ilmu Kesehatan Kulit dan Kelamin FKUGM/RSUP DR. Sardjito Yogyakarta hal ini berkaitan dengan angka Kandidosis dikarenakan peningkatan glikogen vagina dan penurunan $\mathrm{pH}$ oleh karena pakaian rapat dan ketat dan juga konsumsi obat-obatan kontrasepsi. ${ }^{10}$

Hasil penelitian ini berbeda dengan hasil penelitian yang dilakukan di 8 RS Pusat di Medan, Jakarta, Bandung, Semarang, Surabaya, Denpasar dan Ujung Pandang selama tahun 1986-1988 dengan hasil: Pada tahun 1986 dengan jumlah sampel 7561, hasil positif IMS pada laki-laki sebanyak 4504 (59,6\%) dan perempuan sebanyak 3057 (40,4\%). Pada tahun 1987 dengan jumlah sampel 7351, hasil positif IMS pada laki-laki yaitu sebanyak 4523 
(61,5\%) dan pada perempuan sebanyak 2828 (38,5\%). Sedangkan pada tahun 1988 dari jumlah sampel 7276, hasil positif IMS pada laki-laki yaitu sebanyak 4448 (61,5\%) dan pada perempuan sebanyak 2828 (38,5\%). Jadi, pada periode 3 tahun tersebut dapat disimpulkan bahwa laki-laki lebih sering mengalami IMS daripada perempuan. ${ }^{14}$

Dari kelompok umur yang tersering mendapatkan IMS yaitu pasien dengan kelompok umur 20-29 tahun (31,9\%) atau pada kelompok dewasa muda. Penelitian ini hampir sama hasil yang dikemukakan oleh Lukman $\mathrm{H}$ yaitu IMS paling sering terjadi pada kelompok umur 20-24 tahun pada kedua jenis kelamin tersebut. ${ }^{6}$ Hasil yang dikemukakan oleh Drs. Koes Irianto mengenai kelompok umur tersering yaitu 15-30 tahun. ${ }^{2}$

Berdasarkan hasil dari penelitian yang dilakukan di RSUD. Koja dan Puskesmas Cilincing, Jakarta Selatan periode Januari-April 1997 didapatkan hasil dari 312 sampel penelitian dengan jenis kelamin perempuan yaitu usia $<25$ tahun yang positif IMS ada 9 orang $(11,7 \%)$ dan yang negatif IMS ada 39 orang $(16,6 \%)$ sedangkan usia > 25 tahun yang positif IMS ada 68 orang $(88,3 \%)$ dan yang negatif ada 196 orang $(83,4 \%){ }^{12}$

Dari hasil olah data yang saya lakukan didapatkan bahwa kelompok dengan insidensi tertinggi menurut profesi yaitu pegawai swasta diikuti PNS.Dari hasil survey yang dilakukan oleh Yuyun Megaria pada tahun 2009 hal ini dikarenakan profesi PNS diwajibkan untuk bersosialisasi dengan banyak orang. Hal ini memicu adanya keinginan untuk mengamati sisi hidup orang lain hingga memicu terjadinya perselingkuhan yang nantinya menuju pada ketidaksetiaan pada pasangan atau bisa jadi berganti-ganti pasangan seksual. ${ }^{15}$ Menurut pendapat saya alasan yang dikemukakan bisa juga menjadi alasan pada orang dengan profesi pegawai swasta. Dari hasil penelitian saya didapatkan profesi pelaut adalah kelompok terendah yang terinfeksi IMS.Menurut saya hal ini dikarenakan oang dengan profesi pelaut dan pada umumnya pelaut adalah pria memiliki waktu yang kurang untuk berhubungan seksual dengan istri maupun PSK karena seringnya menghabiskan waktu yang panjang di kapal/lautan daripada di daratan.

Secara garis besar IMS terjadi pada kelompok usia produktif yang aktif melakukan hubungan seksual dan berganti-ganti pasangan, misalnya pada PSK sesuai dengan penelitian yang telah dilakukan di Thailand pada tahun 2009, dalam penelitian itu dinyatakan bahwa PS merupakan kelompok resiko tinggi karena seringnya berganti pasangan, menggunakan kondom yang sobek saat berhubungan seksual maupun penolakan terhadap penggunaan kondom. ${ }^{16}$ Melakukan hubungan seksual dengan pasangan yang berganti-ganti dapat meningkatkan resiko terjadinya IMS mengingat faktor penyebabnya karena mikroba yang dapat berpindah dari satu orang yang terinfeksi ke orang lain. ${ }^{2}$

\section{SIMPULAN}

Hasil penelitian terhadap pasien baru dengan diagnosis IMS dengan hasil pemeriksaan laboratorium mikrobiologi di Poliklinik Kulit dan Kelamin RSUP Prof.Dr.R.D.Kandou, Mando periode November 2010 - November 2012 dapat disimpulkan dari hasil pewarnaangram, pola kuman tersering yang menyebabkan IMS adalah Bacillus (basil) gram negatif dan pseudohifa. Kelompok umur tersering yang mengalami IMS adalah pasien dewasa muda dengan kisaran usia 20-29 tahun. Perempuan lebih sering mengalami IMS dibandingkan laki-laki dan dari distribusi pekerjaan, profesi sebagai pegawai swasta lebih sering terkena IMS. 


\section{KEPUSTAKAAN}

1. Widoyono. Penyakit tropis: epidemiologi, penlaran, pencegahan \& pemberantasannya. Erlangga. Jakarta; 2008. Hal. 161,162.

2. Irianto. Mikrobiologi: menguak dunia mikroorganisme. CV.Yrama Widya. Bandung: 2006. Hal. 111-113.

3. Hakim L. Epidemiologi infeksi menular seksual. Dalam: Daili SF, Makes WIB, Zubier F. Infeksi menular seksual. Badan penerbit FKUI. Jakarta; 2011. Hal. 3-6.

4. Brooks, GF, Butel JS, Morse SA. Mikrobiologi Kedokteran Jewetz, Melnick, \& Alderbeg edisi 23. Dalam: Elferia RN, Ramadhani D, Karolina S, Indriyani F, Rianti SSP, Yulia P, editors. Hartanto H, Rachman C, Dimanti A, Diani A, alih bahasa. Jakarta; EGG, 2004. Hal: 717-19.

5. Ferdinand $\mathrm{F}$ \& Ariwibowo M. Praktis Belajar Biologi. Available from: books.google.co.id (access 27 Oktober 2012).

6. Ralph CB \& Martin LP. Obstetri dan Ginekologi. Availbale from: books.google.co.id (access 27 Oktober 2012).

7. Siregar RS. Penyakit Jamur Kulit. Available from: books.google.co.id (access 27 Oktober 2012).

8. Rosana Y. Pemeriksaan laboratorium mikrobiologi infeksi menular seksual. Dalam: Daili SF, Makes WIB, Zubier F. Infeksi menular seksual. Badan penerbit FKUI. Jakarta; 2011. Hal: 25-27.

9. Setiabudi R. Antimikroba: Pengantar antimikroba. Dalamm: Farmakologi dan terapi, Gunawan SG. Badan penerbit FKUI. Jakarta; 2007. Hal: 585.

10. Satiti R. Kandidosis genitalis, Dalam: Daili SF, Makes WIB, Zubier F. Infeksi menular seksual. Badan penerbit FKUI. Jakarta; 2011. Hal: 171-173.

11. Pratiwi S. Genetika dan resistensi. Dalam: Staf Pengajar Fakultas Kedokteran Universitas Indonesia. Buku Ajar Mikrobiologi Kedokteran edisi revisi. Binarupa Aksara. Jakarta; 1994. Hal: 34-8.

12. Iskandar BM.Improved Reproductive Health and STD Services for Women Presenting to Family Planning Services in North Jakarta. 1997. Available from:http://www.popcouncil.org/indo STD (access 20 Januari 2013).

13. Patten JH, Susanti I. Reproductive health and STDs among client's of a women's health clinic in rural Bali, Indonesia. 2001. Available from: http://www.ncbi.nlm.nih.goV/pubmed/l 1177482 (access 20 Januari 2013).

14. Saifuddin AB. Overview of Sexually Transmittes Disease in Indonesia in Issues in Management of STD in Family Planning Settings. Available from: http://www.popcouncil.org/overview of STDs in Indonesia (access 23 Januari $\underline{2013)}$

15. Yuyun M. Konflik rumah tangga Pegawai Negeri Sipil. FISIPOL (Ilmu Komunikasi) 2009. Available

from: http://publikasi.umy.ac.iaVindex.php/komunikasi/article/view/913 (access 23 Januari 2013).

16. Michelle RD, Heather LM, Dusita P, Surang J, George RS, Jay S. Violence victimisation, sexual risk and transmitted infection symptoms among female sex workers in Thailand. Sexually Transmitted Infection 2010 May;86:236-40. 
17. Andrew V, Andrew P, Shannon D, Peter S, Tony L, Greg L, et al. The Prevalence of Sexually Transmitted Infections in Papua New Guinea: A Systemic Review Meta-Analysis. 2010. Available from: http://www.plosone.org/article/info\%3Adoi\%2F 10.1371 \%2Fiournal.pone. 0015586 (Access 23 Januari 2013).

18. Roth A, Williams J, Ly R, Curd K, Brooks D, Arno J, et al. Changing sexually transmitted infection screening protocol will result in improved case finding for trichomonas vaginalis among high-risk female populations. Sexually Transmitted Infection 2011 May;38:398-400.

19. Mayer K, Bush T, Henry K, Overton E, Hammer J, Richardson J, et al. Ongoing sexually transmitted disease acquisition and risk-taking behavior among US HIVinfected patients in primary care: implications for prevention interventions. Sexually Transmitted Infection 2012 January;39:1-7.

20. Heiligenberg M, Rijnders B, Schim VL, Maarten F, Henry JC, Willem I, et al. High prevalence of sexually transmitted infections in HIV-infected men during routine outpatient visits in the Netherlands. Sexually Transmitted Infection 2012 January;39:815.

21. Cassell J, Disckind B. Sexually Transmitted Infections 2013 March;89. Avulable from: http://sti.bmj.com/ (access 2 Maret 2013).

22. U.S Department of Health and Human Service, Office on Woman's Health. Sexually Transmitted Infections: Overview November 2012:1-6.

23. Centers for Disease Control and Prevention. Sexually Transmitted Disease February 2013. Available from: http://www.cdc.gov/std/ (Access 22 Februari 2013).

24. CatrionaOoi, Director, Sexual Health Service, Hunter New England Area Sexual Health Service, Newcastle, and Conjoint Lecturer, School of Medicine and Public Health, Faculty of Health, The University of Newcastle, New South Wales. Testing for Sexually Transmitted Infections. AustPrescr 2007;30:8-13.

25. Hillard W, Stuart B, Willard C. Sexually Transmitted Disease Among American Youth Incidence and Prevalence Estimates, 2000. Perspectives on Sexual and Reproductive Health. 2004 February;36:6-10. 